\title{
Influence of dietary fructose supplementation on visceral organ mass, carbohydrase activity, and mRNA expression of genes involved in small intestinal carbohydrate assimilation in neonatal calves
}

\author{
Ronald J. Trotta, ${ }^{*}$ Alison K. Ward, (1) and Kendall C. Swanson† (1) \\ Department of Animal Sciences, North Dakota State University, Fargo 58108
}

\begin{abstract}
The hypothesis of this experiment was that dietary fructose would influence visceral organ mass, carbohydrase activity, and mRNA expression of carbohydrases and nutrient transporters in the small intestine in neonatal calves. Therefore, our objective was to use the neonatal calf as a model to evaluate the effects of postruminal fructose supply on small intestinal carbohydrate assimilation. Ten calves ( $<7 \mathrm{~d}$ of age; $41.2 \pm$ $1.46 \mathrm{~kg}$ of body weight) were fed milk replacer at $2.0 \%$ of body weight daily $(816 \pm 90.5 \mathrm{~g} / \mathrm{d} ; 272 \pm 30.1 \mathrm{~g} / \mathrm{L}$; dry-matter basis) in 2 equal portions and assigned to the following dietary treatment groups: (1) milk replacer (control; $\mathrm{n}=6$ ) or (2) milk replacer $+2.2 \mathrm{~g}$ of fructose/ $\mathrm{kg}$ of body weight (fructose; $\mathrm{n}=4$ ). Calves were fed dietary treatments for $28 \mathrm{~d}$, with jugular blood sampled every $7 \mathrm{~d}$ before and after the morning feeding. Calves were slaughtered, and visceral weights were recorded. Postruminal carbohydrase activities were assayed. Quantitative real-time PCR was conducted for small intestinal mRNA expression of nutrient transporters [solute carrier family 2 member 5 (GLUT5), solute carrier family 2 member 2 (GLUT2), and solute carrier family 5 member 1 (SGLT1)], carbohydrases (lactase, maltase-glucoamylase, and sucrase-isomaltase), and ketohexokinase $(K H K)$. Data were analyzed using MIXED procedures in SAS version 9.4 (SAS Institute Inc, Cary, NC). Dietary fructose supplementation decreased serum glucose concentration. Small intestinal mass was greater in calves supplemented with fructose. Dietary fructose supplementation did not influence pancreatic $\alpha$-amylase, small intestinal isomaltase, or maltase activities. Sucrase activity was undetected in the small intestine. Dietary fructose supplementation increased
\end{abstract}

Received January 2, 2020.

Accepted June 29, 2020.

*Current address: Department of Animal and Food Sciences, University of Kentucky, Lexington 40546.

†Corresponding author: kendall.swanson@ndsu.edu small intestinal glucoamylase activity per gram of tissue by $30 \%$ and increased maltase-glucoamylase mRNA expression by 6.8 -fold. Dietary fructose supplementation did not influence mRNA expression of GLUT5, SGLT1, GLUT2, or KHK. Dietary fructose supplementation increased small intestinal lactase mRNA expression by 3.1-fold. Sucrase-isomaltase mRNA expression in the small intestine decreased 5.1-fold with dietary fructose supplementation. Dietary fructose supplementation does not induce sucrase activity in neonatal calves; however, sucrase-isomaltase may be transcriptionally regulated by dietary fructose in neonatal calves. More research is needed to compare glucose and fructose at isocaloric intakes to examine effects of dietary fructose at equal metabolizable energy intake.

Key words: digestive enzyme, GLUT5, nutrient transporter, SGLT1, sucrase-isomaltase

\section{INTRODUCTION}

Fructose is a monosaccharide that is passively transported through the apical membrane of the small intestine by the facilitated glucose transporter 5 (GLUT5; Ferraris et al., 2018). Dietary fructose supplementation has been shown to increase GLUT5 mRNA expression and enhance intestinal fructose transport in neonatal rats (Shu et al., 1997). Nutritional regulation of GLUT5 by fructose requires luminal presence of fructose in the human and rodent small intestine (Shu et al., 1998; Ferraris et al., 2018), and GLUT5 expression is directly proportional to intestinal luminal fructose concentration (Shu et al., 1997). Ruminal or abomasal infusions of partially hydrolyzed starch did not affect GLUT5 mRNA expression in the duodenum, jejunum, or ileum of steers (Liao et al., 2010).

Limited information is available on nutritional regulation of small intestinal carbohydrase and nutrient transporter mRNA expression and activity with dietary fructose in ruminants. Regulation of GLUT5 expression and activity by luminal fructose in nonruminants could possibly be attributed to fructose metabolism (Ferraris 
et al., 2018). Phosphorylation of fructose by ketohexokinase (KHK) to fructose-1-phosphate bypasses the regulatory steps of glycolysis, and aldolase B generates glyceraldehyde and dihydroxyacetone phosphate, which continue forward in a concentration-dependent manner. The activity and mRNA expression of KHK and aldolase B, along with the gluconeogenic enzymes glucose-6-phosphatase and fructose 1,6-bisphosphatase, have all been proposed as mediators of GLUT5 regulation by luminal fructose (Douard and Ferraris, 2008).

Previous research in cattle has demonstrated that luminal carbohydrate flow influences pancreatic

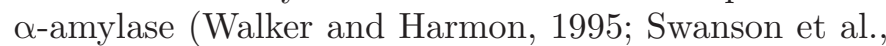
2002) and small intestinal maltase activity (Rodriguez et al., 2004; Gilbert et al., 2015). Supplementation of the artificial sweetener Sucram (Pancosma SA, Geneva, Switzerland) increased maltase activity in the small intestine of ruminating calves (Moran et al., 2014). Those authors suggested that luminal sugar is sensed in the small intestine by T1R2-T1R3 and its associated G-protein, $\alpha$-gustducin, which induces a signaling cascade, leading to a downstream increase in glucagon-like peptide-2 secretion (Moran et al., 2014, 2018). The influence of luminal fructose supply on small intestinal carbohydrase (maltase-glucoamylase, sucrase-isomaltase) or nutrient transporter (GLUT5) activity or mRNA expression in neonatal calves remains equivocal. We hypothesized that dietary fructose supplementation would influence carbohydrase activity and mRNA expression of carbohydrases and nutrient transporters in the small intestine in neonatal calves. Therefore, our objective was to use the neonatal calf as a dietary model to evaluate the effects of postruminal fructose supply for $28 \mathrm{~d}$ on some aspects of small intestinal carbohydrate assimilation.

\section{MATERIALS AND METHODS}

All animal procedures were approved by the North Dakota State University (Fargo, ND) Institutional Animal Care and Use Committee (Protocol \#A17037).

\section{Animals and Diets}

Twelve male Holstein calves ( $<7 \mathrm{~d}$ of age; $\mathrm{BW}=40.5$ $\pm 1.80 \mathrm{~kg}$ ) were sourced from a local dairy, castrated by banding, and housed and fed in individual pens (0.91 $\times 1.2 \mathrm{~m})$ in a temperature-controlled environment $\left(14^{\circ} \mathrm{C}\right)$ with Tenderfoot flooring (Tandem Products Inc., Minneapolis, MN) at the North Dakota State University Animal Nutrition and Physiology Center (Fargo). Calves were fed milk replacer at $2.0 \%$ of BW daily $(816 \pm 90.5 \mathrm{~g} / \mathrm{d} ; 272 \pm 30.1 \mathrm{~g} / \mathrm{L})$ on a DM basis
(Nurture Calf Formula Basic Bov Medicated; Provimi Inc., Brookville, $\mathrm{OH}$ ) in equal amounts at 0730 and $1930 \mathrm{~h}$ during a 7 -d adaptation period and throughout the 28-d feeding period. During the adaptation period, calves were trained to consume reconstituted milk replacer from a bucket and acclimated to their pens. Calves were bucket fed because minimal differences have been found in abomasal digesta flow compared with nipple feeding when calves are trained to bucket feed for at least $7 \mathrm{~d}$ (Abe et al., 1979). Following the adaptation period, calves were randomly assigned to dietary treatment groups: (1) milk replacer (control) or (2) milk replacer $+2.2 \mathrm{~g}$ of fructose (Archer Daniels Midland Co., Chicago, IL) $/ \mathrm{kg}$ of BW (fructose). The amount of fructose fed was $9.9 \%$ of total DMI in fructose calves, which is similar to dietary sugar inclusion levels used in previous studies with lactating dairy cows (Penner and Oba, 2009) and dairy calves (Gilbert et al., 2016). The amount of fructose fed supplied 7.8\% of total calculated ME intake. Calves had ad libitum access to water. Approximately $1.5 \mathrm{~L}$ of warm water was measured into each bucket, and fructose was added and dissolved for the fructose treatment. Milk replacer was added, and diets were hand-mixed for $30 \mathrm{~s}$ with a whisk. Calves were not fed starter at any point before or during the experiment.

Bulk samples of the milk replacer were obtained and analyzed for chemical composition (93.3\% DM, 93.4\% OM, $21.7 \%$ CP, $20.0 \%$ crude fat, $4.63 \%$ starch, $0.70 \%$ Ca, $0.51 \% \mathrm{P}$ ) including DM, ash, and N using a Kjeltec Auto 1030 Analyzer (Foss Tecator AB, Höganäs, Sweden; AOAC, 1990). Gross energy and ME concentrations were calculated using the equations for whole milk, milk replacers, and milk-derived ingredients (NRC, 2001). Crude protein was calculated by multiplying $\mathrm{N}$ concentration $\times 6.25$. Crude fat, $\mathrm{Ca}$, and $\mathrm{P}$ concentrations were analyzed using standard procedures (AOAC, 1990). Starch concentrations were analyzed using the methods of Herrera-Saldana and Huber (1989). Calves were fed dietary treatments over a $28-\mathrm{d}$ period and then slaughtered. Two calves in the fructose treatment were removed from the study due to illness resulting from navel infections, and all data pertaining to those calves were excluded from analyses.

\section{Sample Collection}

Blood samples were collected by jugular venipuncture on d 0 (first day of feeding dietary treatments), $7,14,21$, and 28 , before and $2 \mathrm{~h}$ after the morning feeding. Blood samples were set to clot for $20 \mathrm{~min}$ and centrifuged at $2,000 \times g$ for $20 \mathrm{~min}$ at $4^{\circ} \mathrm{C}$, and serum was stored at $-20^{\circ} \mathrm{C}$ for later analysis. Glucose 
concentrations in serum samples were measured using the hexokinase/glucose-6-phosphate dehydrogenase procedure (Farrance, 1987). Serum urea-N concentrations were analyzed using the QuantiChrom Urea Assay Kit (BioAssay Systems, Hayward, CA) containing o-phthaldialdehyde and primaquine diphosphate, based on the procedures of Jung et al. (1975). Serum nonesterified fatty acid (NEFA) concentrations were determined using the modified methods of Eisemann et al. (1988) with a commercial enzymatic kit (HR Series NEFA-HR; Fujifilm Waco Diagnostics, Mountain View, CA). Serum glucose, urea-N, and NEFA procedures were adapted for use on a microplate spectrophotometer (Synergy H1; BioTek Instruments Inc., Winooski, VT). L-Lactate concentrations in serum were analyzed using the L-lactate dehydrogenase procedure (Gutmann and Wahlefeld, 1974) on an ultraviolet-visible spectrophotometer (DU 800; Beckman Coulter Inc., Brea, CA).

Body weights were measured every $7 \mathrm{~d}$, with a 2 -d weight recorded at the start of the collection period. On d 29, each calf was fed in 30-min increments and slaughtered $2 \mathrm{~h}$ after feeding, via captive bolt and exsanguination. Calves were fed in 30-min increments to account for slaughter time (approximately $30 \mathrm{~min}$ per calf) and to ensure that all calves were slaughtered at $2 \mathrm{~h}$ after feeding, to correspond with sampling of blood that was collected $2 \mathrm{~h}$ after feeding. Previous research in rats has shown that fructose feeding before tissue collection induces a broader range of genes than does tissue collection during the fasted state (Koo et al., 2008). Viscera were removed, weighed, and separated for individual weights and subsample collection. Omental, mesenteric, and perirenal fat was removed, composited, and weighed. Visceral fat was calculated as the sum of omental, mesenteric, and perirenal fat masses (Favre et al., 2017). The gastrointestinal tract, foregut (reticulorumen, omasum, and abomasum), small intestine, large intestine, pancreas, liver (gallbladder removed), spleen, heart, kidney, and lung masses were recorded on a wettissue basis after removing digesta. The small intestine was removed at the pyloric and ileocecal junction and cut into 4 segments: duodenum, proximal jejunum, distal jejunum, and ileum. Demarcations of the 4 sections of the small intestine were made using the modified methods of Bauer et al. (2001a). Briefly, 1-m sections were measured from the pylorus and ileocecal junction to represent portions of the duodenum and ileum, respectively. The remainder of the small intestine was measured and cut in half to represent the proximal and distal jejunum. One-meter segments were cut and sampled from the midpoint of the previously cut sections. Each 1-m intestinal segment was weighed and scraped using a glass microscope slide (Siddons, 1968). The tis- sue remaining after the mucosal scrape was weighed, and mucosal density calculated. The longissimus muscle was removed from the 12th rib and trimmed of all external fat and epimysial connective tissue. Subsamples of the pancreas, liver, longissimus muscle (12th to 13th rib), duodenum, proximal jejunum, distal jejunum, and ileum were flash-frozen in isopentane (2-methylbutane; J. T. Baker, Center Valley, PA) that was super-cooled in liquid nitrogen and then stored at $-80^{\circ} \mathrm{C}$ until further analyses (Keomanivong et al., 2016). The liver, longissimus muscle, and pancreas were lyophilized and ground, and crude fat concentrations were measured using standard procedures (AOAC, 1990).

\section{Quantitative Real-Time PCR}

Samples of duodenal, proximal and distal jejunal, and ileal mucosa from each calf were used for quantitative real-time PCR analysis. The RNA was extracted and purified using the Qiagen RNeasy Mini Kit, and genomic DNA (gDNA) was eliminated using a gDNA Eliminator column (Qiagen Inc., Germantown, MD). RNA concentrations were quantified using a fluorometer (Qubit 3.0; Thermo Fisher Scientific Inc., Waltham, $\mathrm{MA}$ ), and RNA purity was assessed using a microplate spectrophotometer (Synergy H1; BioTek Instruments Inc.) at wavelengths 230,260 , and $280 \mathrm{~nm}$. Complementary DNA was synthesized from $1,000 \mathrm{ng} / \mu \mathrm{L}$ of RNA for each sample, using the iScript cDNA Synthesis Kit (Bio-Rad Laboratories, Hercules, CA) containing reverse transcriptase. Hydrolysis probes were used for each gene containing 6-carboxyfluorescein (FAM) dye and minor groove binder (MGB) label. Hydrolysis probes were sourced (TaqMan; Applied Biosystems, Grand Island, NY), except $M G A M$, which was custom designed (PrimeTime Std qPCR Assay; Integrated DNA Technologies Inc., Coralville, IA) using the NCBI reference sequence from GenBank (XM_024991197.1; Bethesda, MD) to produce amplicons bridging exonexon junctions (Cui et al., 2007). Amplification efficiency was assessed for each primer and probe set by generating a 5-point 10-fold serial dilution standard curve (Table 1). Gene expression was quantified using a 7500 Fast Real-Time PCR System (Applied Biosystems), with TaqMan Fast Advanced Master Mix, using a $20-\mu \mathrm{L}$ total reaction volume $(10 \mu \mathrm{L}$ of Master Mix; 7 $\mu \mathrm{L}$ of nuclease-free water; $2 \mu \mathrm{L}$ of $\mathrm{cDNA} ; 1 \mu \mathrm{L}$ probe) for all genes.

Systematic and common gene names, probe assay numbers, and primer efficiencies are reported in Table 1. Quantitative real-time PCR analysis (intraplate $\mathrm{CV}=0.562$, interplate $\mathrm{CV}=0.357$ ) was conducted with 40 oscillating cycles of denaturing $\left(95^{\circ} \mathrm{C}\right.$ for $\left.20 \mathrm{~s}\right)$ 
Table 1. Selected genes in the small intestine that were analyzed using quantitative real-time PCR

\begin{tabular}{llr}
\hline Name & Gene symbol & Assay no. \\
\hline Solute carrier family 2 member 5 (GLUT5) & SLC2A5 & Bt03258299_g1 \\
Solute carrier family 2 member 2 (GLUT2) & SLC2A2 & Bt03258678_m1 \\
Solute carrier family 5 member 1 (SGLT1) & SLC5A1 & Bt03223889_m1 \\
Sucrase-isomaltase & SI & Bt03259068_m1 \\
Maltase-glucoamylase & MGAM & XM_024991197.1 \\
Lactase & LCT & Bt04285580_m1 \\
Ketohexokinase & KHK & Bt03249204_m1 \\
3-Actin & ACTB & Bt03279174_g1 \\
RNA polymerase II subunit A & POLR2A & Bt04294167_m1 \\
Succinate dehydrogenase complex flavoprotein subunit A & SDHA & Bt04307498_m1 \\
Glyceraldehyde 3-phosphate dehydrogenase & GAPDH & Bt03279174_g1 \\
\hline
\end{tabular}

${ }^{1}$ Maltase-glucoamylase was assayed using a PrimeTime Assay Standard Probe from Integrated DNA Technologies Inc. (Coralville, IA). Probe: 5'-/56FAM/CAGCATTCC/ZEN/ATCTGGCACCTCTGA/3IABkFQ/-3'; reverse primer: 5'-CGGCGAATTTCAATCCCAAAT-3'; forward primer: 5'-GTTCCAGTCCCTCTCAACATAC-3'.

and annealing/extension $\left(60^{\circ} \mathrm{C}\right.$ for $\left.30 \mathrm{~s}\right)$ temperatures. Multiple reference genes were evaluated for the stability of expression across treatments and intestinal segments: $\beta$-actin $(A C T B)$, glyceraldehyde-3-phosphate dehydrogenase $(G A P D H)$, RNA polymerase II subunit A (POLR2A), and succinate dehydrogenase complex flavoprotein subunit A ( $S D H A)$. Stability was assessed by geNorm analysis (Vandesompele et al., 2002) using qbase+ software (Biogazelle, Zwijnarrde, Belgium). The gene with the lowest M-value $(<0.05)$ was $G A P$ $D H$, which was therefore selected as the reference gene. Experimental genes of interest were ketohexokinase $(K H K)$, solute carrier family 2 member 5 (SLC2A5; GLUT5), solute carrier family 5 member 1 (SLC5A1; $S G L T 1$ ), solute carrier family 2 member 2 (SLC2A2; GLUT2), sucrase-isomaltase (SI), maltase-glucoamylase $(M G A M)$, and lactase $(L C T)$. Relative mRNA expression was calculated using the $2^{-\Delta \Delta \mathrm{Ct}}$ method (Livak and Schmittgen, 2001), with GAPDH used as the reference gene.

\section{Digestive Enzyme Activity}

Methods used to measure postruminal carbohydrase activities were similar to those described by Trotta et al. (2020a,b). Pancreatic $(500 \pm 7.38 \mathrm{mg})$ or intestinal $(513 \pm 21.5 \mathrm{mg})$ tissue were weighed and diluted with $9 \mathrm{~g} / \mathrm{L}$ of $\mathrm{NaCl}$ solution in $10-\mathrm{mL}$ storage tubes. Samples were homogenized (Kinematica Polytron PT 10/35; Brinkmann Instruments Inc., Riverview, FL), and protein concentrations were measured using the bicinchoninic acid procedure (Pierce BCA Protein Assay Kit, cat. no. 23225; Thermo Fisher Scientific Inc.) using BSA as the standard (Smith et al., 1985). Activity of $\alpha$-amylase was determined using the procedure from Wallenfels et al. (1978), adapted for analysis of pancreatic tissue. $\alpha$-Amylase activity was assayed ki- netically with a commercially available reagent (Amylase Reagent Set; cat. no. A533; Teco Diagnostics, Anaheim, CA) containing p-nitrophenyl-D-maltoheptaoside as the substrate. The reagent was reconstituted $(0.225$ $\mathrm{m} M$ p-nitrophenyl-D-maltoheptaoside; 6,250 U/L of Q-glucosidase (Saccharomyces cerevisiae); 2,500 U/L of glucoamylase (Rhizopus sp.); $12.5 \mathrm{mM} \mathrm{NaCl} ; 1.25 \mathrm{mM}$ $\mathrm{CaCl}_{2} ; 12.5 \mathrm{mM}$ buffer) with $24 \mathrm{~mL}$ of distilled water and pre-warmed to $39^{\circ} \mathrm{C}$ in an incubator.

Each intestinal segment was assayed for brush border carbohydrases: lactase, maltase, isomaltase, sucrase, and glucoamylase. Intestinal disaccharidases (lactase, maltase, isomaltase, and sucrase) were assayed using modified methods of Dahlqvist (1964). Lactose, maltose, isomaltose, and sucrose were used as the substrates, respectively. Soluble starch was the substrate used to analyze for glucoamylase activity (Kidder et al., 1972). The intestinal homogenate $(500 \mu \mathrm{L})$ was combined with $500 \mu \mathrm{L}$ of $25 \mathrm{mM}$ potassium phosphate buffer (Turner and Moran, 1982) and $100 \mu \mathrm{L}$ of $60 \mathrm{mM}$ substrate solution in a $1.5-\mathrm{mL}$ centrifuge tube. Tubes were incubated for $30 \mathrm{~min}$ at $39^{\circ} \mathrm{C}$ in a water bath. The reaction was terminated by heating tubes for 2 min in a $90^{\circ} \mathrm{C}$ water bath, followed by drenching in an ice bath. Tubes were then centrifuged at $4,000 \times g$ for 20 min at $4^{\circ} \mathrm{C}$. Liberated glucose was measured using the hexokinase/glucose-6-phosphate dehydrogenase procedure (Farrance, 1987).

All assays were optimized to achieve maximal velocity through the linear concentration and adapted for use on a microplate spectrophotometer (Synergy $\mathrm{H} 1$; BioTek Instruments Inc.) at $39^{\circ} \mathrm{C}$. One unit (U) of pancreatic $\alpha$-amylase activity equals $1 \mu \mathrm{mol}$ of $\mathrm{p}$ nitrophenol produced per minute. One unit (U) of small intestinal carbohydrase activity equals $1 \mu \mathrm{mol}$ of glucose produced per minute for glucoamylase, lactase, and sucrase, and $0.5 \mu \mathrm{mol}$ of glucose produced per min- 
Table 2. Effects of dietary fructose supplementation on BW, nutrient intake, and growth performance of neonatal calves, expressed on a DM basis

\begin{tabular}{|c|c|c|c|c|}
\hline \multirow[b]{2}{*}{ Item } & \multicolumn{2}{|c|}{ Treatment } & \multirow[b]{2}{*}{$\mathrm{SEM}^{2}$} & \multirow[b]{2}{*}{$P$-value } \\
\hline & Control & Fructose $^{1}$ & & \\
\hline Day-0 BW, kg & 39.9 & 43.2 & 2.26 & 0.29 \\
\hline $\mathrm{BW}$ at slaughter, $\mathrm{kg}$ & 54.0 & 57.1 & 3.47 & 0.51 \\
\hline $\mathrm{ADG}, \mathrm{kg} / \mathrm{d}$ & 0.51 & 0.50 & 0.054 & 0.91 \\
\hline $\mathrm{G}: \mathrm{F}^{3}$ & 0.64 & 0.54 & 0.050 & 0.18 \\
\hline Total DMI, g/d & 803 & 928 & 49.5 & 0.09 \\
\hline Milk replacer intake, ${ }^{4} \mathrm{~g} / \mathrm{d}$ & 803 & 836 & 47.1 & 0.60 \\
\hline GE intake ${ }^{5} \mathrm{Mcal} / \mathrm{d}$ & 4.11 & 4.65 & 0.250 & 0.14 \\
\hline ME intake, Mcal/d & 3.83 & 4.33 & 0.270 & 0.14 \\
\hline CP intake, $\mathrm{g} / \mathrm{d}$ & 174 & 182 & 10.2 & 0.60 \\
\hline Crude fat intake, $\mathrm{g} / \mathrm{d}$ & 161 & 167 & 9.4 & 0.60 \\
\hline Starch intake, $\mathrm{g} / \mathrm{d}$ & 37.2 & 38.7 & 2.18 & 0.60 \\
\hline
\end{tabular}

ute for maltase and isomaltase. Blanks of each intestinal homogenate and substrate solution were quantified for endogenous glucose concentrations and subtracted from the total amount of product produced per minute. Enzyme activity data are expressed as units per gram of tissue and units per gram of protein.

\section{Statistical Analysis}

Data were analyzed as a completely randomized design in SAS (version 9.4, SAS Institute Inc., Cary, NC) using calf as the experimental unit. Nutrient intake, visceral organ mass, fat content, and pancreatic measurements were analyzed using the MIXED procedure of SAS for fixed effect of treatment and random effect of calf. Day-0 BW (BW on d 0, prior to feeding) was included in the model as a covariate for visceral organ mass data. The MIXED procedure of SAS was used to assess fixed effects, including a repeated measures statement. Variance-covariance structures for the repeated measures statement were assessed for fit using Bayesian information criterion for antedependence 1, autoregressive 1, compound symmetry, simple, and unstructured, including calf as the subject. Serum glucose, NEFA, Llactate, and urea- $\mathrm{N}$ concentrations were analyzed using the repeated measures statement of the MIXED procedure of SAS for fixed effects of day, time, treatment, and their interactions, and random effect of calf. The initial metabolite measurement (d 0 , before feeding) was used as a covariate for serum-dependent variables. Small intestinal mass, protein concentration, mucosal density, carbohydrase activity, and mRNA expression data were analyzed using the repeated measures statement of the
MIXED procedure for fixed effects of site, treatment, and the site $\times$ treatment interaction, and random effect of calf. Least squares means were separated using the least significant difference approach, protected by a significant $F$-test. Results were considered significant if $P \leq 0.05$. Tendencies were declared when $0.05<P$ $\leq 0.10$.

\section{RESULTS}

\section{Nutrient Intake, Growth Performance, and Serum Metabolites}

Day-0 BW and BW at slaughter, ADG, and ratio of gain to feed were not affected by dietary fructose supplementation (Table 2). By design, dietary fructose supplementation tended to increase $(P=0.09)$ total DMI. Dietary fructose supplementation did not influence milk replacer intake, gross energy or ME intake, CP intake, crude fat intake, or starch intake.

No interactions occurred among day, time, or treatment for serum glucose or urea- $\mathrm{N}$ concentrations (data not shown). A day $\times$ time interaction was detected for serum NEFA concentrations, where NEFA concentrations were greater $(P=0.03) 2 \mathrm{~h}$ after feeding on $\mathrm{d} 7$, 14, 21, and 28 but not d 0 (data not shown). Dietary fructose supplementation decreased $(P<0.001)$ serum glucose concentrations (Figure 1A) but did not affect serum urea-N concentrations (Figure 1B) or serum NEFA concentrations (Figure 1C). Serum glucose concentrations were greater $(P<0.001) 2 \mathrm{~h}$ after feeding than before feeding, but serum urea- $\mathrm{N}$ concentrations were not influenced by feeding time (Supplemental 
Table S1, https://doi.org/10.3168/jds.2020-18145). Effects of day on serum metabolite concentrations are reported in Supplemental Table S2 (https://doi.org/10 $.3168 /$ jds.2020-18145). We found a time $\times$ treatment interaction for serum L-lactate concentrations, where L-lactate concentrations were greater $(P=0.02)$ in
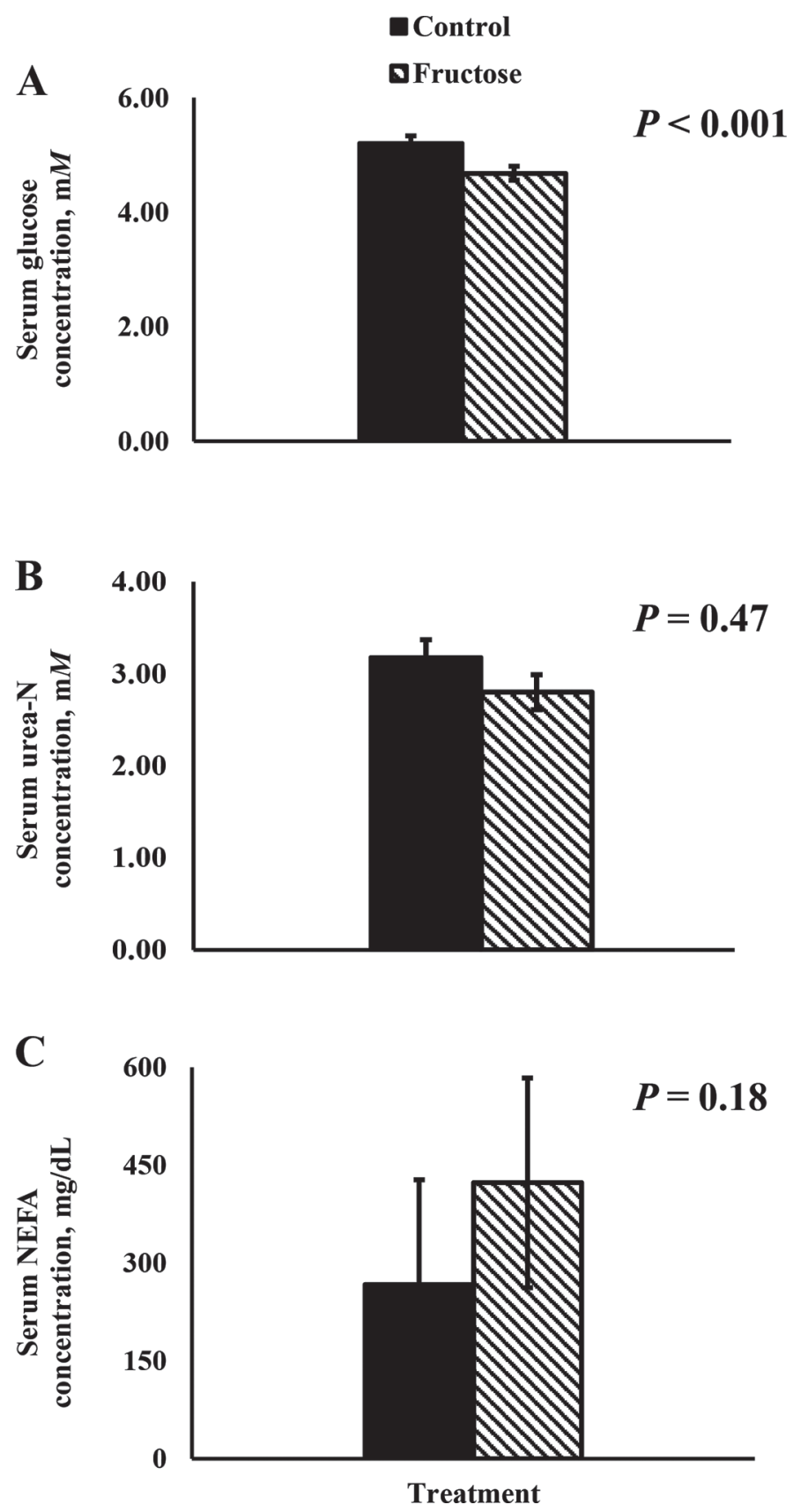

Figure 1. Least squares means \pm SEM (fructose, $n=4$ ) for serum (A) glucose, (B) urea-N, and (C) nonesterified fatty acid (NEFA) concentrations in neonatal calves fed milk replacer (control) or milk replacer $+2.2 \mathrm{~g}$ of fructose $/ \mathrm{kg}$ of BW (fructose). control calves before feeding compared with fructose calves, and $2 \mathrm{~h}$ after feeding (Figure 2).

\section{Visceral Organ Mass and Fat Content}

Mass of the gastrointestinal tract, foregut complex, omasum, abomasum, large intestine, cecum, colon, spleen, pancreas, heart, lungs, and longissimus muscle were not affected by dietary fructose supplementation (Table 3). Small intestinal mass $(\mathrm{g})$ was greater $(P=$ 0.04) in fructose calves than in control calves but was not influenced as a proportion of BW. Dietary fructose supplementation tended to decrease $(P=0.08)$ reticuloruminal mass and tended to increase $(P<0.10)$ liver mass and kidney mass when expressed per kilogram of BW.

Visceral, omental, and mesenteric fat mass were not affected by dietary fructose supplementation (Table 4). Perirenal fat mass ( $\mathrm{g}$ and $\mathrm{g} / \mathrm{kg}$ of $\mathrm{BW}$ ) tended to increase $(P<0.08)$ in calves supplemented with fructose. Fat concentrations of the longissimus muscle, pancreas, or liver were not influenced by dietary fructose supplementation.

\section{Digestive Enzyme Activity}

No site $\times$ treatment interactions occurred for small intestinal mass, mucosal density, protein concentration, maltase, or isomaltase activities (Table 5). Tendencies were detected for site $x$ treatment interactions for glucoamylase and lactase activity per gram of tissue. Dietary fructose supplementation tended to increase $(P=0.07)$ glucoamylase activity per gram of tissue in the duodenum, distal jejunum, and ileum; however, proximal jejunal glucoamylase activity per gram of tissue tended to be lesser $(P=0.07)$ in calves fed fructose (Figure 3). Dietary fructose supplementation tended to decrease $(P=0.10)$ lactase activity per gram of tissue in the proximal portions of the intestine (duodenum, proximal jejunum) but not distally (Figure 4). Sucrase activity was not detected in any segment of the small intestine in calves from either treatment.

Dietary fructose supplementation did not influence small intestinal site mass (duodenum, jejunum, proximal jejunum, ileum; g or $\mathrm{g} / \mathrm{kg}$ of $\mathrm{BW}$ ) or mucosal density (Table 5). Pancreatic and small intestinal protein concentrations were not influenced by dietary fructose supplementation. Fructose supplementation did not influence pancreatic $\alpha$-amylase activity. Glucoamylase activity per gram of tissue increased $(P=0.05)$ with dietary fructose supplementation. Isomaltase, maltase, and lactase activities were not influenced by dietary fructose supplementation. 
Small intestinal sampling site mass was greatest $(P$ $<0.001$ ) in the ileum and lowest in the proximal and distal jejunum (Supplemental Table S3, https://doi .org/10.3168/jds.2020-18145). When expressed per kilogram of BW, duodenal and ileal mass were greater $(P$ $<0.001)$ than proximal and distal jejunal mass. Protein concentration did not differ among sites of the small intestine. Mucosal density was greatest $(P<0.001)$ in the proximal jejunum. Glucoamylase activity was not influenced by site of the small intestine. Isomaltase and maltase activities per gram of protein were not influenced by site of the small intestine. Isomaltase and maltase activity per gram of tissue were greatest $(P<$ 0.03 ) in the distal jejunum. Lactase activity per gram of tissue and activity per gram of protein were greatest in the proximal jejunum and lowest in the ileum $(P<$ 0.001).

\section{mRNA Expression}

No site $\times$ treatment interactions were found for any of the small intestinal genes measured in the current study (Table 6). Dietary fructose supplementation did not influence mRNA expression of GLUT5, SGLT1, GLUT2, or KHK. Dietary fructose supplementation increased $(P=0.002) L C T$ mRNA expression 3.1-fold. Sucrase-isomaltase mRNA expression in the small intestine decreased $(P=0.006)$ 5.1-fold with dietary fructose supplementation. Dietary fructose supplementation increased $(P<0.001) M G A M$ mRNA expression in the small intestine 6.8 -fold.
The mRNA expression of GLUT5 was greatest in the duodenum and proximal jejunum and lowest in the distal jejunum and ileum $(P<0.001$; Supplemental Table S4, https://doi.org/10.3168/jds.2020-18145). The mRNA expression of SGLT1 and GLUT2 were greatest in the proximal jejunum and lowest in the distal jejunum and ileum $(P<0.001)$. Lactase mRNA expression was greatest $(P=0.003)$ in the proximal jejunum. Furthermore, duodenal and distal jejunum $L C T$ mRNA expression was greater $(P=0.003)$ than ileal $L C T$ mRNA expression. Sucrase-isomaltase and KHK mRNA expression did not differ across sites of the small intestine.

\section{DISCUSSION}

In the current study, fructose was supplemented at $2.2 \mathrm{~g} / \mathrm{kg}$ of BW to calves fed milk replacer, and this subsequently resulted in a $15.6 \%$ increase in DMI and a $13.1 \%$ increase in ME intake for calves in the fructose treatment. Although it is possible that some of the variables measured in the current study could have been influenced by differences in caloric intake between treatments, recent studies with dairy calves have found that increasing levels of milk replacer intake, and therefore DM and energy intake, do not result in increased small intestinal or hepatic mass (Azevedo et al., 2016; Koch et al., 2019). Small intestinal mass was greater in fructose calves, and reticuloruminal mass tended to be greater in control calves in the current study, suggesting a differential increase in small intestinal mass relative

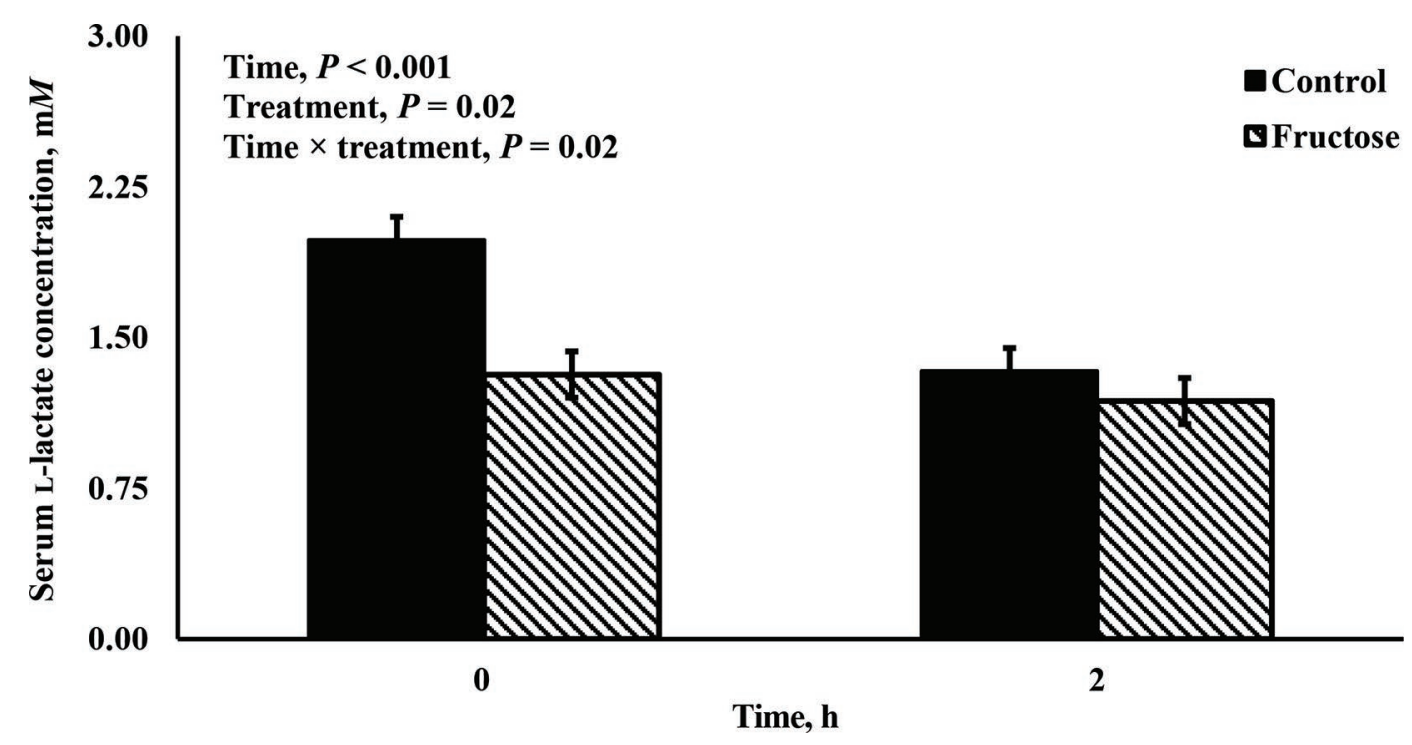

Figure 2. Least squares means \pm SEM (fructose, $\mathrm{n}=4$ ) for the time $\times$ treatment interaction for L-lactate concentrations in serum from calves fed milk replacer (control) or milk replacer $+2.2 \mathrm{~g}$ of fructose $/ \mathrm{kg}$ of BW (fructose). 
Table 3. Effects of dietary fructose supplementation on visceral organ mass

\begin{tabular}{|c|c|c|c|c|}
\hline \multirow[b]{2}{*}{ Item } & \multicolumn{2}{|c|}{ Treatment } & \multirow[b]{2}{*}{$\mathrm{SEM}^{2}$} & \multirow[b]{2}{*}{$P$-value } \\
\hline & Control & Fructose $^{1}$ & & \\
\hline \multicolumn{5}{|c|}{ Gastrointestinal tract } \\
\hline & 6.41 & 6.71 & 0.413 & 0.60 \\
\hline $\mathrm{g} / \mathrm{kg}$ of $\mathrm{BW}$ & 113 & 122 & 9.9 & 0.30 \\
\hline \multicolumn{5}{|c|}{ Foregut complex ${ }^{3}$} \\
\hline $\mathrm{g}$ & 649 & 579 & 31.8 & 0.14 \\
\hline $\mathrm{g} / \mathrm{kg}$ of $\mathrm{BW}$ & 11.4 & 10.6 & 0.79 & 0.44 \\
\hline \multicolumn{5}{|l|}{ Reticulorumen } \\
\hline $\mathrm{g}$ & 310 & 263 & 17.7 & 0.08 \\
\hline $\mathrm{g} / \mathrm{kg}$ of $\mathrm{BW}$ & 5.50 & 4.82 & 0.434 & 0.28 \\
\hline \multicolumn{5}{|l|}{ Omasum } \\
\hline $\mathrm{g}$ & 76.0 & 65.2 & 9.82 & 0.44 \\
\hline $\mathrm{g} / \mathrm{kg}$ of BW & 1.34 & 1.16 & 0.175 & 0.47 \\
\hline \multicolumn{5}{|l|}{ Abomasum } \\
\hline $\mathrm{g}$ & 263 & 251 & 14.9 & 0.57 \\
\hline $\mathrm{g} / \mathrm{kg}$ of $\mathrm{BW}$ & 4.59 & 4.58 & 0.337 & 0.98 \\
\hline \multicolumn{5}{|l|}{ Small intestine } \\
\hline $\mathrm{kg}$ & 1.24 & 1.27 & 0.009 & 0.04 \\
\hline $\mathrm{g} / \mathrm{kg}$ of $\mathrm{BW}$ & 22.1 & 23.3 & 0.64 & 0.20 \\
\hline \multicolumn{5}{|l|}{ Large intestine ${ }^{4}$} \\
\hline $\mathrm{g}$ & 401 & 418 & 25.1 & 0.63 \\
\hline $\mathrm{g} / \mathrm{kg}$ of $\mathrm{BW}$ & 7.13 & 7.60 & 0.577 & 0.56 \\
\hline \multicolumn{5}{|l|}{ Cecum } \\
\hline $\mathrm{g}$ & 63.5 & 53.7 & 4.99 & 0.18 \\
\hline $\mathrm{g} / \mathrm{kg}$ of $\mathrm{BW}$ & 1.13 & 0.98 & 0.082 & 0.19 \\
\hline \multicolumn{5}{|l|}{ Colon } \\
\hline $\mathrm{g}$ & 337 & 364 & 26.7 & 0.48 \\
\hline $\mathrm{g} / \mathrm{kg}$ of $\mathrm{BW}$ & 6.00 & 6.63 & 0.591 & 0.45 \\
\hline \multicolumn{5}{|l|}{ Spleen } \\
\hline $\mathrm{g}$ & 162 & 167 & 11.3 & 0.72 \\
\hline $\mathrm{g} / \mathrm{kg}$ of $\mathrm{BW}$ & 2.85 & 3.02 & 0.172 & 0.40 \\
\hline \multicolumn{5}{|l|}{ Pancreas } \\
\hline $\mathrm{g}$ & 56.5 & 53.8 & 4.84 & 0.69 \\
\hline $\mathrm{g} / \mathrm{kg}$ of $\mathrm{BW}$ & 0.989 & 0.988 & 0.0936 & 0.99 \\
\hline \multicolumn{5}{|l|}{ Liver } \\
\hline $\mathrm{kg}$ & 1.36 & 1.55 & 0.077 & 0.11 \\
\hline $\mathrm{g} / \mathrm{kg}$ of BW & 23.9 & 27.9 & 1.17 & 0.04 \\
\hline \multicolumn{5}{|l|}{ Kidney } \\
\hline $\mathrm{g}$ & 247 & 283 & 16.6 & 0.14 \\
\hline $\mathrm{g} / \mathrm{kg}$ of $\mathrm{BW}$ & 4.33 & 5.13 & 0.322 & 0.10 \\
\hline \multicolumn{5}{|l|}{ Heart } \\
\hline $\mathrm{g}$ & 445 & 433 & 16.4 & 0.58 \\
\hline $\mathrm{g} / \mathrm{kg}$ of $\mathrm{BW}$ & 7.86 & 7.87 & 0.425 & 0.99 \\
\hline \multicolumn{5}{|l|}{ Lungs } \\
\hline $\mathrm{g}$ & 786 & 848 & 57.8 & 0.44 \\
\hline $\mathrm{g} / \mathrm{kg}$ of $\mathrm{BW}$ & 13.6 & 15.2 & 0.93 & 0.25 \\
\hline \multicolumn{5}{|c|}{ Longissimus muscle } \\
\hline $\mathrm{g}$ & 49.0 & 53.9 & 3.55 & 0.34 \\
\hline $\mathrm{g} / \mathrm{kg}$ of $\mathrm{BW}$ & 0.860 & 0.975 & 0.0565 & 0.17 \\
\hline
\end{tabular}

${ }^{1}$ Fructose was provided in the diet at $2.2 \mathrm{~g} / \mathrm{kg}$ of BW.

${ }^{2}$ Control, $\mathrm{n}=6$; fructose, $\mathrm{n}=4$.

${ }^{3}$ Calculated as sum of reticulorumen + omasum + abomasum.

${ }^{4}$ Calculated as sum of cecum + colon.

to reticulorumen, potentially because of the increased supply of postruminal fructose.

The observed differences in serum glucose and L-lactate concentrations suggest that dietary fructose supplementation may have altered carbohydrate metabolism in neonatal calves. Many previous studies in calves
Table 4. Effects of dietary fructose supplementation on gross fat content of the viscera, kidney, longissimus muscle, pancreas, and liver

\begin{tabular}{|c|c|c|c|c|}
\hline \multirow[b]{2}{*}{ Item } & \multicolumn{2}{|c|}{ Treatment } & \multirow[b]{2}{*}{$\mathrm{SEM}^{2}$} & \multirow[b]{2}{*}{$P$-value } \\
\hline & Control & Fructose $^{1}$ & & \\
\hline \multicolumn{5}{|l|}{ Visceral fat $^{3}$} \\
\hline $\mathrm{g}$ & 594 & 615 & 46.0 & 0.74 \\
\hline $\mathrm{g} / \mathrm{kg}$ of $\mathrm{BW}$ & 10.5 & 11.3 & 0.88 & 0.23 \\
\hline \multicolumn{5}{|l|}{ Omental fat } \\
\hline $\mathrm{g}$ & 183 & 161 & 11.9 & 0.22 \\
\hline $\mathrm{g} / \mathrm{kg}$ of BW & 3.19 & 2.95 & 0.218 & 0.44 \\
\hline \multicolumn{5}{|l|}{ Mesenteric fat } \\
\hline $\mathrm{g}$ & 224 & 207 & 24.1 & 0.62 \\
\hline $\mathrm{g} / \mathrm{kg}$ of $\mathrm{BW}$ & 3.94 & 3.81 & 0.449 & 0.83 \\
\hline \multicolumn{5}{|l|}{ Perirenal fat } \\
\hline $\mathrm{g}$ & 187 & 247 & 21.8 & 0.08 \\
\hline $\mathrm{g} / \mathrm{kg}$ of BW & 3.30 & 4.49 & 0.404 & 0.07 \\
\hline \multicolumn{5}{|l|}{ Longissimus muscle fat ${ }^{4}$} \\
\hline $\mathrm{mg} / \mathrm{g}$ & 3.98 & 3.41 & 0.810 & 0.61 \\
\hline $\mathrm{g} /$ longissimus muscle & 0.40 & 0.38 & 0.079 & 0.83 \\
\hline $\mathrm{mg} / \mathrm{kg}$ of $\mathrm{BW}$ & 7.57 & 6.92 & 1.740 & 0.78 \\
\hline \multicolumn{5}{|l|}{ Pancreatic fat ${ }^{5}$} \\
\hline $\mathrm{mg} / \mathrm{g}$ & 37.9 & 28.2 & 5.33 & 0.20 \\
\hline $\mathrm{g} /$ pancreas & 5.38 & 4.16 & 0.850 & 0.30 \\
\hline $\mathrm{mg} / \mathrm{kg}$ of BW & 99.7 & 72.5 & 13.70 & 0.16 \\
\hline \multicolumn{5}{|l|}{ Hepatic fat ${ }^{5}$} \\
\hline $\mathrm{mg} / \mathrm{g}$ & 4.73 & 4.44 & 0.370 & 0.57 \\
\hline $\mathrm{g} /$ liver & 15.5 & 18.0 & 1.92 & 0.33 \\
\hline $\mathrm{mg} / \mathrm{kg}$ of $\mathrm{BW}$ & 285 & 315 & 23.1 & 0.35 \\
\hline
\end{tabular}

${ }^{1}$ Fructose was provided in the diet at $2.2 \mathrm{~g} / \mathrm{kg}$ of $\mathrm{BW}$.

${ }^{2}$ Control, $\mathrm{n}=6$; fructose, $\mathrm{n}=4$.

${ }^{3}$ Calculated as sum of omental + mesenteric + perirenal fat.

${ }^{4}$ Fat in longissimus muscle sample taken between the 12th and 13th rib. Fat concentrations are expressed on a DM basis.

${ }^{5}$ Fat concentrations are expressed on a DM basis.

have demonstrated suppressed glucose concentrations in response to feeding fructose (Daniels et al., 1974; Keller et al., 1998; Becker et al., 2000), and this effect is thought to be independent of insulin sensitivity (Tyler and Ramsey, 1993; Pantophlet et al., 2016). In support of these previous studies, dietary fructose supplementation decreased serum glucose concentrations in the current study, suggesting that the dietary model was comparable to previous research in dairy calves. Rapid catabolism of fructose by ketohexokinase to fructose1-phosphate increases AMP concentrations (Caliceti et al., 2017), which is a negative allosteric regulator of fructose 1,6-bisphosphatase (Timson, 2019). Therefore, decreased serum glucose concentrations in response to dietary fructose supplementation could potentially be because of accumulation of fructose-1-phosphate and AMP or changes in the ATP:AMP, which might lead to a reduction in gluconeogenesis.

Dietary fructose supplementation increased small intestinal glucoamylase concentration by $30.0 \%$ and MGAM mRNA expression 6.8-fold. Approximately $80 \%$ of the apparent maltase activity is derived from SI 
and the remaining $20 \%$ from MGAM in nonruminants (Lin et al., 2012). Differential regulation of MGAM (increase) and $S I$ (decrease) mRNA expression with dietary fructose supplementation may explain why no change appeared in maltase activity, yet glucoamylase activity increased. Koch et al. (2019) found that the level of milk replacer intake did not influence mRNA expression of $L C T, M G A M$, or $S I$ in calves. Their findings demonstrate that the level of DM or energy intake does not influence small intestinal carbohydrase mRNA expression in calves, which may suggest that changes in small intestinal carbohydrase mRNA expression with dietary fructose supplementation occurred independent of DM or energy intake in the current study.

Gilbert et al. (2016) reported that replacing $15 \%$ of lactose with fructose on a gross energy basis decreased total-tract DM, energy, and N digestibility. It should be noted that small intestinal lactase activity was numerically lower by $21 \%$ in fructose-fed calves in the current study, which potentially could have resulted in decreased digestibility. Dietary fructose supplementation increased $L C T \mathrm{mRNA}$ expression in the small intestine 3.1-fold in the current study. Because lactase activity was numerically lower in calves fed fructose, and feed- ing fructose may have decreased digestibility, it seems logical that $L C T$ mRNA expression would increase in an attempt to increase LCT protein synthesis and activity. However, regulation of digestive enzyme activity is complex, and numerous regulatory mechanisms are involved in controlling lactase activity (Auricchio, 1994).

In humans, dietary sucrose or fructose increases sucrase activity in the small intestine (Rosensweig and Herman, 1968). Additionally, dietary fructose supplementation can induce sucrase activity in patients with congenital SI deficiency (Greene et al., 1972). However, several authors have failed to detect sucrase activity in the small intestine of cattle (Dollar and Porter, 1957; Huber et al., 1961; Siddons, 1968; Trotta et al., 2020a) and sheep (Walker, 1959; Shirazi-Beechey et al., 1989; Trotta et al., 2020b). Moreover, abomasal infusion of sucrose does not induce sucrase activity in lambs (Swanson and Harmon, 1997). Similar to previous reports, sucrase activity was not detected in the small intestine in the current study. This demonstrates that dietary fructose supplementation does not induce sucrase activity in neonatal calves. In the current study, dietary fructose supplementation decreased SI mRNA expres-

Table 5. Effects of small intestinal site and dietary fructose supplementation on pancreatic and small intestinal protein concentration and carbohydrase activities

\begin{tabular}{|c|c|c|c|c|c|c|}
\hline \multirow[b]{2}{*}{ Item } & \multicolumn{2}{|c|}{ Treatment } & \multirow[b]{2}{*}{$\mathrm{SEM}^{2}$} & \multicolumn{3}{|c|}{$P$-value } \\
\hline & Control & Fructose $^{1}$ & & Site $^{3}$ & $\operatorname{Trt}^{4}$ & Site $\times$ Trt \\
\hline $\begin{array}{l}\text { Pancreatic protein, mg/g } \\
\alpha \text {-Amylase }\end{array}$ & 88.3 & 80.5 & 3.70 & - & 0.14 & - \\
\hline $\mathrm{U} / \mathrm{g}$ of pancreas & 70.8 & 102 & 18.0 & - & 0.21 & - \\
\hline $\mathrm{U} / \mathrm{g}$ of protein & 805 & 1,330 & 262 & - & 0.16 & - \\
\hline \multicolumn{7}{|l|}{ Small intestinal site mass } \\
\hline $\mathrm{g}$ & 66.9 & 72.6 & 3.13 & $<0.001$ & 0.17 & 0.46 \\
\hline $\mathrm{g} / \mathrm{kg}$ of BW & 1.24 & 1.26 & 0.092 & $<0.001$ & 0.89 & 0.47 \\
\hline Mucosal density, \% & 63.4 & 66.8 & 1.62 & $<0.001$ & 0.12 & 0.81 \\
\hline Small intestinal protein, $\mathrm{mg} / \mathrm{g}$ & 70.6 & 72.7 & 2.08 & 0.29 & 0.44 & 0.35 \\
\hline \multicolumn{7}{|l|}{ Glucoamylase } \\
\hline $\mathrm{U} / \mathrm{g}$ of intestine $\mathrm{s}^{5}$ & 0.480 & 0.624 & 0.0566 & 0.23 & 0.05 & 0.07 \\
\hline $\mathrm{U} / \mathrm{g}$ of protein & 6.86 & 8.56 & 0.852 & 0.33 & 0.13 & 0.11 \\
\hline \multicolumn{7}{|l|}{ Isomaltase } \\
\hline $\mathrm{U} / \mathrm{g}$ of intestine & 0.486 & 0.497 & 0.0265 & 0.04 & 0.74 & 0.13 \\
\hline $\mathrm{U} / \mathrm{g}$ of protein & 7.09 & 6.90 & 0.488 & 0.14 & 0.77 & 0.48 \\
\hline \multicolumn{7}{|l|}{ Lactase } \\
\hline $\mathrm{U} / \mathrm{g}$ of intestine ${ }^{6}$ & 5.86 & 4.62 & 0.707 & $<0.001$ & 0.19 & 0.10 \\
\hline $\mathrm{U} / \mathrm{g}$ of protein & 79.5 & 62.5 & 9.40 & $<0.001$ & 0.18 & 0.13 \\
\hline \multicolumn{7}{|l|}{ Maltase } \\
\hline $\mathrm{U} / \mathrm{g}$ of intestine & 0.97 & 1.01 & 0.041 & 0.03 & 0.42 & 0.26 \\
\hline $\mathrm{U} / \mathrm{g}$ of protein & 14.1 & 14.0 & 0.85 & 0.16 & 0.96 & 0.55 \\
\hline
\end{tabular}

${ }^{1}$ Fructose was provided in the diet at $2.2 \mathrm{~g} / \mathrm{kg}$ of $\mathrm{BW}$

${ }^{2}$ Control, $\mathrm{n}=6$; fructose, $\mathrm{n}=4$.

${ }^{3}$ Site LSM are presented in supplemental materials: https://doi.org/10.3168/jds.2020-18145.

${ }^{4}$ Trt $=$ treatment.

${ }^{5}$ Interactive LSM are presented in Figure 3.

${ }^{6}$ Interactive LSM are presented in Figure 4 
sion in the small intestine. However, results from the current study might suggest that fructose presence in the small intestine could selectively decrease SI mRNA expression through a negative feedback mechanism via product inhibition. Because fructose is a product of sucrose hydrolysis, it is possible that luminal or absorbed fructose, or both, decrease SI mRNA expression after feeding fructose for $28 \mathrm{~d}$ to neonatal calves.

To our knowledge, no studies have evaluated the effects of dietary fructose on the regulation of GLUT5 mRNA expression in the ruminant small intestine. In contrast to our hypothesis, dietary fructose supplementation did not influence GLUT5 mRNA expression in the small intestine of neonatal calves fed milk replacer. Previous research in steers demonstrated that GLUT5 does not respond to ruminal or abomasal infusions of $3.1 \mathrm{~g} / \mathrm{kg}$ of BW of starch hydrolysate (Liao et al., 2010). Douard and Ferraris (2008) discussed the complex relationships between age, luminal fructose supply, and induction of GLUT5 in neonatal (milk only), weaning (milk + solid feed), and postweaning (feed only) rats. In general, GLUT5 mRNA expression is nutritionally regulated by luminal fructose during weaning (14-28 d of age) and after weaning ( $>28$ d of age) in rats (David et al., 1995; Monteiro and Ferraris, 1997; Shu et al., 1998). However, in neonatal rats ( $<14 \mathrm{~d}$ of age), GLUT5 mRNA expression can increase with luminal fructose and glucocorticoid supply but not luminal fructose alone (Douard et al., 2008a,b; Suzuki et al., 2011).
Calves in the current study were fed milk replacer with no solid feed. Thus, results from the current study in neonatal calves support the work of others in rats, suggesting that GLUT5 expression is not influenced solely by luminal fructose supply in mammals during the neonatal phase. However, it remains unknown whether GLUT5 can be nutritionally regulated by luminal fructose in weaned or mature cattle.

Sodium-dependent glucose cotransporter-1 is thought to be the primary apical membrane transporter for glucose absorption in ruminants (Shirazi-Beechey, 1995). Many studies in ruminants have concluded that glucose transport activity and SGLT1 protein abundance were greatest in milk-fed lambs and declined with age (Shirazi-Beechey et al., 1989; Shirazi-Beechey et al., 1991). Shirazi-Beechey et al. (1991) demonstrated that duodenal infusions of a $30 \mathrm{~m} M$ glucose solution for 4 $\mathrm{d}$ in adult sheep increased the rate of glucose transport 40- to 80-fold, which was also accompanied by an increase in SGLT1 protein abundance. Furthermore, Dyer et al. (1994) demonstrated that duodenal fructose infusions can increase jejunal SGLT1 protein abundance in lambs. Those authors concluded that luminal sugar is sensed in the intestine, independent of glucose metabolism, and that the inducing sugar does not need to be a substrate of SGLT1 (Dyer et al., 1994; Moran et al., 2014). However, several studies with postruminal carbohydrate infusions in cattle have found little or no change in sodium-dependent glucose uptake activity

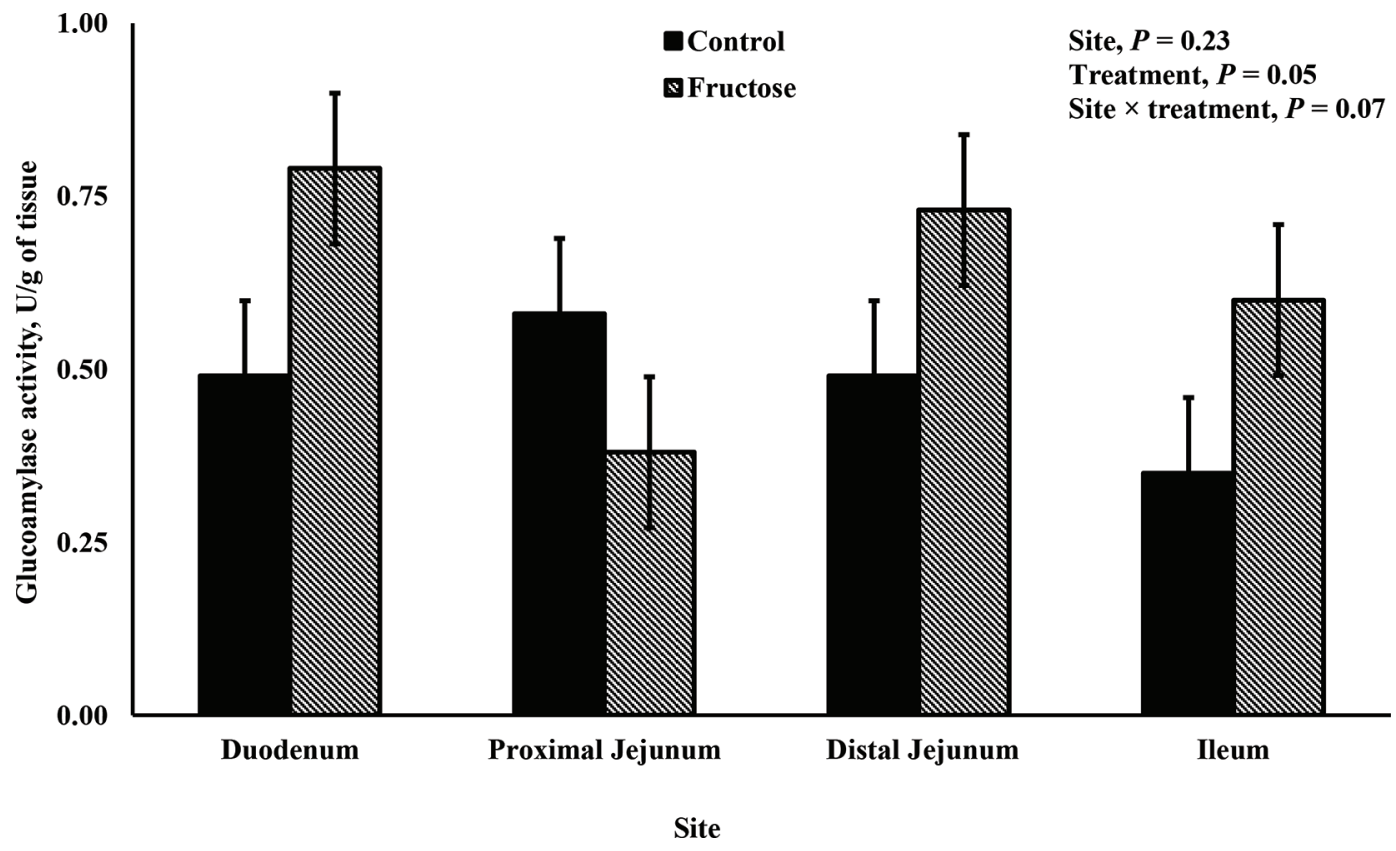

Figure 3. Least squares means \pm SEM (fructose, $n=4$ ) for the site $\times$ treatment interaction for glucoamylase activity per gram of intestine in the duodenum, proximal jejunum, distal jejunum, and ileum from calves fed milk replacer (control) or milk replacer $+2.2 \mathrm{~g}$ of fructose/kg of BW (fructose). 


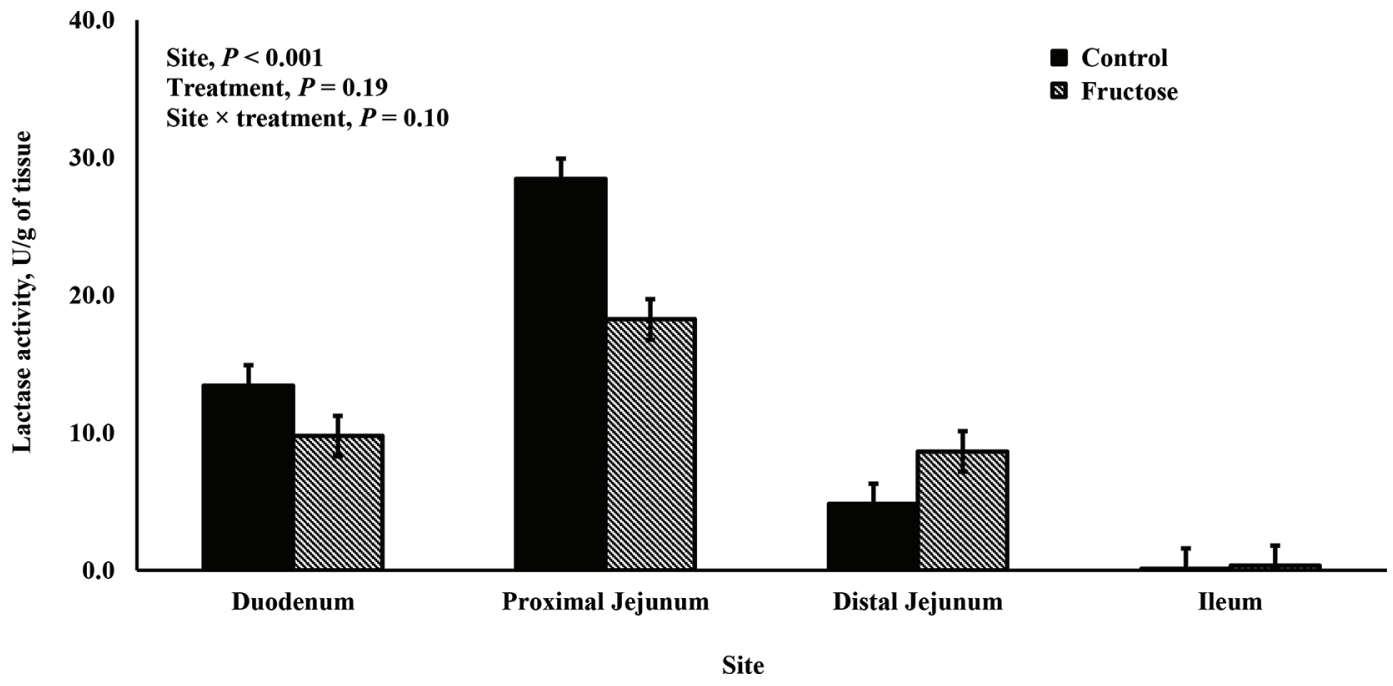

Figure 4. Least squares means \pm SEM (fructose, $\mathrm{n}=4$ ) for the site $\times$ treatment interaction for lactase activity per gram of intestine in the duodenum, proximal jejunum, distal jejunum, and ileum from calves fed milk replacer (control) or milk replacer $+2.2 \mathrm{~g}$ of fructose/kg of BW (fructose).

(Bauer et al., 2001a,b; Rodriguez et al., 2004; Guimaraes et al., 2007), SGLT1 mRNA expression (Liao et al., 2010), or SGLT1 protein abundance (Guimaraes et al., 2007). Similarly, there were no effects of dietary fructose supplementation on SGLT1 or GLUT2 mRNA expression in the small intestine in the current study, further suggesting that carbohydrate transporters in the small intestine of cattle are not sensitive to luminal carbohydrate flow.

\section{CONCLUSIONS}

Data from the current study demonstrate that dietary fructose supplementation may influence small intestinal carbohydrase activity and mRNA expression in neonatal calves. Altered carbohydrate metabolism in response to dietary fructose supplementation may be supported by decreased serum glucose and L-lactate concentrations. Dietary fructose supplementation did not influence nutrient transporter expression but differentially regulated $L C T, M G A M$, and $S I$ mRNA expression in the small intestine of neonatal calves. Sucrase-isomaltase may be transcriptionally regulated by fructose in the small intestine of neonatal calves; however, feeding fructose does not induce sucrase activity in neonatal calves. Future research should focus on differential regulation of small intestinal function between glucose and fructose in ruminants at isocaloric intakes, to examine effects of dietary fructose at equal ME intake. Additional research is needed to quantify

Table 6. Effects of small intestinal site and dietary fructose supplementation on relative mRNA expression of genes in the small intestine

\begin{tabular}{|c|c|c|c|c|c|c|c|}
\hline \multirow[b]{2}{*}{ Gene } & \multirow{2}{*}{$\begin{array}{c}\text { Fold } \\
\text { change }\end{array}$} & \multicolumn{2}{|c|}{ Treatment } & \multirow[b]{2}{*}{$\mathrm{SEM}^{3}$} & \multicolumn{3}{|c|}{$P$-value } \\
\hline & & Control & Fructose $^{2}$ & & Site $^{4}$ & $\operatorname{Trt}^{5}$ & Site $\times$ Trt \\
\hline$K H K$ & $\downarrow_{1.03}$ & 1.15 & 1.12 & 0.237 & 0.21 & 0.93 & 0.44 \\
\hline GLUT5 & $\uparrow 1.14$ & 0.655 & 0.744 & 0.1440 & $<0.001$ & 0.64 & 0.66 \\
\hline SGLT1 & $\downarrow 1.21$ & 1.00 & 0.83 & 0.122 & $<0.001$ & 0.28 & 0.69 \\
\hline GLUT2 & $\uparrow 1.21$ & 0.87 & 1.05 & 0.142 & $<0.001$ & 0.34 & 0.94 \\
\hline$L C T$ & $\uparrow 3.10$ & 0.70 & 2.17 & 0.329 & 0.003 & 0.002 & 0.22 \\
\hline$S I$ & $\downarrow 5.07$ & 1.36 & 0.27 & 0.281 & 0.20 & 0.006 & 0.69 \\
\hline$M G A M$ & $\uparrow 6.80$ & 1.94 & 13.2 & 2.36 & 0.86 & $<0.001$ & 0.91 \\
\hline
\end{tabular}

${ }^{1} G A P D H$ was used as the reference gene.

${ }^{2}$ Fructose was provided in the diet at $2.2 \mathrm{~g} / \mathrm{kg}$ of BW.

${ }^{3}$ Control, $\mathrm{n}=6$; fructose, $\mathrm{n}=4$.

${ }^{4}$ Site LSM are presented in supplemental materials: https://doi.org/10.3168/jds.2020-18145.

${ }^{5}$ Trt $=$ treatment. 
fructose transport and metabolism in ruminants and to determine whether increasing postruminal supply of fructose may yield potential production benefits.

\section{ACKNOWLEDGMENTS}

The authors thank Laurie Geyer and Marsha Kapphahn of the North Dakota State University (NDSU; Fargo) Animal Science Nutrition Laboratory and Mara Hirchert of the NDSU Animal Science Genetics Laboratory for their skilled assistance with sample analyses. We also thank Lauren Hanna (NDSU Department of Animal Science) for assistance with statistical analyses. We thank the staff at the NDSU Animal Nutrition and Physiology Center for assistance with animal care and management. This work was partially supported by the North Dakota State Board of Agricultural Research and Education (Fargo). The authors declare no conflict of interest.

\section{REFERENCES}

Abe, M., T. Iriki, K. Kondoh, and H. Shibui. 1979. Effects of nipple or bucket feeding of milk-substitute on rumen by-pass and on rate of passage in calves. Br. J. Nutr. 41:175-181. https://doi.org/10 $.1079 /$ BJN19790024.

AOAC. 1990. Official Methods of Analysis. 15th ed. Assoc. Off. Anal. Chem., Arlington, VA.

Auricchio, S. 1994. Regulatory mechanisms of the lactase activity in adult intestine. Gastroenterology 106:1376-1378. https://doi.org/ 10.1016/0016-5085(94)90033-7.

Azevedo, R. A., F. S. Machado, M. M. Campos, D. R. G. Lopes, S. F. Costa, H. C. Mantovani, F. C. F. Lopes, M. I. Marcondes, L. G. R. Pereira, T. R. Tomich, and S. G. Coelho. 2016. The effects of increasing amounts of milk replacer powder added to whole milk on passage rate, nutrient digestibility, ruminal development, and body composition in dairy calves. J. Dairy Sci. 99:8746-8758. https://doi.org/10.3168/jds.2016-11410.

Bauer, M. L., D. L. Harmon, D. W. Bohnert, A. F. Branco, and G. B. Huntington. 2001a. Influence of $\alpha$-linked glucose on sodiumglucose cotransport activity along the small intestine in cattle. J. Anim. Sci. 79:1917-1924. https://doi.org/10.2527/2001.7971917x.

Bauer, M. L., D. L. Harmon, K. R. McLeod, and G. B. Huntington. 2001b. Influence of $\alpha$-linked glucose on jejunal sodium-glucose co-transport activity in ruminants. Comp. Biochem. Physiol. A Mol. Integr. Physiol. 129:577-583. https://doi.org/10.1016/S1095 -6433(01)00296-3.

Becker, C. J., H. L. Keller, W. P. Weiss, and L. B. Willett. 2000. Response of newborn calves to oral fructose, sorbitol, or lactose supplements. J. Appl. Anim. Res. 17:185-196. https://doi.org/10 .1080/09712119.2000.9706301.

Caliceti, C., D. Calabria, A. Roda, and A. F. G. Cicero. 2017. Fructose intake, serum uric acid, and cardiometabolic disorders: a critical review. Nutrients 9:395. https://doi.org/10.3390/nu9040395.

Cui, W., D. D. Taub, and K. Gardner. 2007. qPrimerDepot: A primer database for quantitative real time PCR. Nucleic Acids Res. 35(Database):D805-D809. https://doi.org/10.1093/nar/gkl767.

Dahlqvist, A. 1964. Method of assay of intestinal disaccharidases. Anal. Biochem. 7:18-25. https://doi.org/10.1016/0003-2697(64)90115-0.

Daniels, L. B., J. L. Perkins, D. Krieder, D. Tugwell, and D. Carpenter. 1974. Blood glucose and fructose in the newborn ruminant. J. Dairy Sci. 57:1196-1200. https://doi.org/10.3168/jds.S0022 -0302(74)85036-8.
David, E. S., D. S. Cingari, and R. P. Ferraris. 1995. Dietary induction of intestinal fructose absorption in weaning rats. Pediatr. Res. 37:777-782. https://doi.org/10.1203/00006450-199506000-00017.

Dollar, A. M., and J. W. G. Porter. 1957. Utilization of carbohydrates by the young calf. Nature 179:1299-1300. https://doi.org/10.1038/ $1791299 \mathrm{a} 0$.

Douard, V., H. I. Choi, S. Elshenawy, D. Lagunoff, and R. P. Ferraris. 2008a. Developmental reprogramming of rat GLUT5 requires glucocorticoid receptor translocation to the nucleus. J. Physiol. 586:3657-3673. https://doi.org/10.1113/jphysiol.2008.155226.

Douard, V., X. L. Cui, P. Soteropoulos, and R. P. Ferraris. 2008b. Dexamethasone sensitizes the neonatal intestine to fructose induction of intestinal fructose transporter (SLC2A5) function. Endocrinology 149:409-423. https://doi.org/10.1210/en.2007-0906.

Douard, V., and R. P. Ferraris. 2008. Regulation of the fructose transporter GLUT5 in health and disease. Am. J. Physiol. Endocrinol. Metab. 295:E227-E237. https://doi.org/10.1152/ajpendo.90245 2008 .

Dyer, J., D. Scott, R. B. Beechey, A. D. Care, K. S. Abbas, and S. P. Shirazi-Beechey. 1994. Dietary regulation of intestinal glucose transport. Pages 65-72 in Mammalian Brush-border Membrane Proteins, Part II. M. J. Lentze, R. J. Grand, and H. Y. Naim, ed. Thieme Verlag, New York, NY

Eisemann, J. H., G. B. Huntington, and C. L. Ferrell. 1988. Effects of dietary clenbuterol on metabolism of the hindquarters in steers. J. Anim. Sci. 66:342-353. https://doi.org/10.2527/jas1988.662342x.

Farrance, I. 1987. Plasma glucose methods, A review. Clin. Biochem. Rev. 8:55-68.

Favre, G., C. Grangeon-Chapon, C. Raffaelli, F. François-Chalmin, A. Iannelli, and V. Esnault. 2017. Perirenal fat thickness measured with computed tomography is a reliable estimate of perirenal fat mass. PLoS One 12:e0175561. https://doi.org/10.1371/journal .pone.0175561.

Ferraris, R. P., J. Y. Choe, and C. R. Patel. 2018. Intestinal absorption of fructose. Annu. Rev. Nutr. 38:41-67. https://doi.org/10.1146/ annurev-nutr-082117-051707.

Gilbert, M. S., A. J. Pantophlet, H. Berends, A. M. Pluschke, J. J. G. C. van den Borne, W. H. Hendriks, H. A. Schols, and W. J. J. Gerrits. 2015. Fermentation in the small intestine contributes substantially to intestinal starch disappearance in calves. J. Nutr. 145:1147-1155. https://doi.org/10.3945/jn.114.208595.

Gilbert, M. S., A. J. Pantophlet, J. J. G. C. van den Borne, W. H. Hendriks, H. A. Schols, and W. J. J. Gerrits. 2016. Effects of replacing lactose from milk replace by glucose, fructose, or glycerol on energy partitioning in veal calves. J. Dairy Sci. 99:1121-1132. https://doi.org/10.3168/jds.2015-10062.

Greene, H. L., F. B. Stifel, and R. H. Herman. 1972. Dietary stimulation of sucrase in a patient with sucrase-isomaltase deficiency. Biochem. Med. 6:409-418. https://doi.org/10.1016/0006 -2944(72)90085-3.

Guimaraes, K. C., S. R. Hazelton, J. C. Matthews, K. C. Swanson, D. L. Harmon, and A. F. Branco. 2007. Influence of starch and casein administered postruminally on small intestinal sodium-glucose cotransport activity and expression. Braz. Arch. Biol. Technol. 50:963-970. https://doi.org/10.1590/S1516-89132007000700007.

Gutmann, I., and A. W. Wahlefeld. 1974. L(+) lactate determination with lactate dehydrogenase and NAD. Pages 1464-1468 in Methods of Enzymatic Analysis, Vol. 3. H. Bergmeyer, ed. Academic Press, Cambridge, MA.

Herrera-Saldana, R., and J. T. Huber. 1989. Influence of varying protein and starch degradabilities on performance of lactating cows. J. Dairy Sci. 72:1477-1483. https://doi.org/10.3168/jds.S0022 $-0302(89) 79257-2$.

Huber, J. T., N. L. Jacobson, R. S. Allen, and P. A. Hartman. 1961. Digestive enzyme activities in the young calf. J. Dairy Sci. 44:14941501. https://doi.org/10.3168/jds.S0022-0302(61)89911-6.

Jung, D., H. Biggs, J. Erikson, and P. U. Ledyard. 1975. New colorimetric reaction for end-point, continuous-flow, and kinetic measurement of urea. Clin. Chem. 21:1136-1140. https://doi.org/10 $.1093 /$ clinchem/21.8.1136. 
Keller, H. L., L. I. Gherman, R. E. Kosa, D. C. Borger, W. P. Weiss, and L. B. Willett. 1998. Kinetics of plasma fructose and glucose when lactose and fructose are used as energy supplements for neonatal calves. J. Anim. Sci. 76:2197-2204. https://doi.org/10.2527/ 1998.7682197x.

Keomanivong, F. E., C. O. Lemley, L. E. Camacho, R. Yunusova, P. P. Borowicz, J. S. Caton, A. M. Meyer, K. A. Vonnahme, and K. C. Swanson. 2016. Influence of nutrient restriction and melatonin supplementation of pregnant ewes on maternal and fetal pancreatic digestive enzymes and insulin-containing clusters. Animal 10:440-448. https://doi.org/10.1017/S1751731115002219.

Kidder, D. E., F. W. G. Hill, and J. A. Stevens. 1972. Automatic measurement of some mucosal carbohydrases. Clin. Chim. Acta 37:491-501. https://doi.org/10.1016/0009-8981(72)90474-3.

Koch, C., C. Gerbert, D. Frieten, G. Dusel, K. Eder, R. Zitnan, and H. M. Hammon. 2019. Effects of ad libitum milk replacer feeding and butyrate supplementation on the epithelial growth and development of the gastrointestinal tract in Holstein calves. J. Dairy Sci. 102:8513-8526. https://doi.org/10.3168/jds.2019-16328.

Koo, H. Y., M. A. Wallig, B. H. Chung, T. Y. Nara, B. H. S. Cho, and M. T. Nakamura. 2008. Dietary fructose induces a wide range of genes with distinct shift in carbohydrate and lipid metabolism in fed and fasted rat liver. Biochim. Biophys. Acta 1782:341-348. https://doi.org/10.1016/j.bbadis.2008.02.007.

Liao, S. F., D. L. Harmon, E. S. Vanzant, K. R. McLeod, J. A. Boling, and J. C. Matthews. 2010. The small intestinal epithelia of beef steers differentially express sugar transporter messenger ribonucleic acid in response to abomasal versus ruminal infusion of starch hydrolysate. J. Anim. Sci. 88:306-314. https://doi.org/10 $.2527 /$ jas.2009-1992.

Lin, A. H. M., B. L. Nichols, R. Quezada-Calvillo, S. E. Avery, L. Sim, D. R. Rose, H. Y. Naim, and B. R. Hamaker. 2012. Unexpected high digestion rate of cooked starch by the Ct-maltase-glucoamylase small intestine mucosal $\alpha$-glucosidase subunit. PLoS One 7:e35473. https://doi.org/10.1371/journal.pone.0035473.

Livak, K. J., and T. D. Schmittgen. 2001. Analysis of relative gene expression data using real-time quantitative PCR and the $2^{-\Delta \Delta \mathrm{Ct}}$ method. Methods. 25:402-408. https://doi.org/10.1006/meth.2001 .1262 .

Monteiro, I. M., and R. P. Ferraris. 1997. Precocious enhancement of intestinal fructose uptake by diet in adrenalectomized rat pups. Pediatr. Res. 41:353-358. https://doi.org/10.1203/00006450 -199703000-00008.

Moran, A. W., M. Al-Rammahi, D. J. Batchelor, D. M. Bravo, and S. P. Shirazi-Beechey. 2018. Glucagon-like peptide-2 and the enteric nervous system are components of cell-cell communication pathway regulating intestinal $\mathrm{Na}^{+} /$glucose co-transport. Front. Nutr. 5:101. https://doi.org/10.3389/fnut.2018.00101.

Moran, A. W., M. Al-Rammahi, C. Zhang, D. Bravo, S. Calsamiglia, and S. P. Shirazi-Beechey. 2014. Sweet taste receptor expression in ruminant intestine and its activation by artificial sweeteners to regulate glucose absorption. J. Dairy Sci. 97:4955-4972. https:// doi.org/10.3168/jds.2014-8004.

NRC. 2001. Nutrient Requirements of Dairy Cattle. 7th rev. ed. Natl. Acad. Press, Washington, DC.

Pantophlet, A. J., M. S. Gilbert, J. J. G. C. van den Borne, W. J. J. Gerrits, H. Roelofsen, M. G. Priebe, and R. J. Vonk. 2016. Lactose in milk replacer can partly be replaced by glucose, fructose, or glycerol without affecting insulin sensitivity in veal calves. J. Dairy Sci. 99:3072-3080. https://doi.org/10.3168/jds.2015-10277.

Penner, G. B., and M. Oba. 2009. Increasing dietary sugar concentration may improve dry matter intake, ruminal fermentation, and productivity of dairy cows in the postpartum phase of the transition period. J. Dairy Sci. 92:3341-3353. https://doi.org/10.3168/ jds.2008-1977.

Rodriguez, S. M., K. C. Guimaraes, J. C. Matthews, K. R. McLeod, R. L. Baldwin IV, and D. L. Harmon. 2004. Influence of abomasal carbohydrates on small intestinal sodium-dependent glucose cotransporter activity and abundance in steers. J. Anim. Sci. 82:3015-3023. https://doi.org/10.2527/2004.82103015x.
Rosensweig, N. S., and R. H. Herman. 1968. Control of jejunal sucrase and maltase activity by dietary sucrose or fructose in man: A model for the study of enzyme regulation in man. J. Clin. Invest. 47:2253-2262. https://doi.org/10.1172/JCI105910.

Shirazi-Beechey, S. P. 1995. Molecular biology of intestinal glucose transport. Nutr. Res. Rev. 8:27-41.

Shirazi-Beechey, S. P., B. A. Hirayama, Y. Wang, D. Scott, M. W. Smith, and E. M. Wright. 1991. Ontogenic development of lamb intestinal sodium-glucose co-transporter is regulated by diet. J. Physiol. 437:699-708. https://doi.org/10.1113/jphysiol.1991 .sp018620.

Shirazi-Beechey, S. P., R. B. Kemp, J. Dyer, and R. B. Beechey. 1989. Changes in the functions of the intestinal brush border membrane during the development of the ruminant habit in lambs. Comp. Biochem. Physiol. B 94:801-806. https://doi.org/10.1016/0305 -0491(89)90169-7.

Shu, R., E. S. David, and R. P. Ferraris. 1997. Dietary fructose enhances intestinal fructose transport and GLUT5 expression in weaning rats. Am. J. Physiol. 272:G446-G453. https://doi.org/10 .1152 /ajpgi.1997.272.3.G446.

Shu, R., E. S. David, and R. P. Ferraris. 1998. Luminal fructose modulates fructose transport and GLUT-5 expression in small intestine of weaning rats. Am. J. Physiol. 274:G232-G239. https://doi.org/ 10.1152/ajpgi.1998.274.2.G232.

Siddons, R. C. 1968. Carbohydrase activities in the bovine digestive tract. Biochem. J. 108:839-844. https://doi.org/10.1042/ bj1080839.

Smith, P. K., R. I. Krohn, G. T. Hermanson, A. K. Mallia, F. H. Gartner, M. D. Provenzano, E. K. Fujimoto, N. M. Goeke, B. J. Olson, and D. C. Klenk. 1985. Measurement of protein using bicinchoninic acid. Anal. Biochem. 150:76-85. https://doi.org/10 .1016/0003-2697(85)90442-7.

Suzuki, T., V. Douard, K. Mochizuki, T. Goda, and R. P. Ferraris. 2011. Diet-induced epigenetic regulation in vivo of the intestinal fructose transporter Glut5 during development of rat small intestine. Biochem. J. 435:43-53. https://doi.org/10.1042/BJ20101987.

Swanson, K. C., and D. L. Harmon. 1997. Influence of abomasal sucrose infusion on small intestinal disaccharidase activity in lambs. J. Anim. Sci. 75(Suppl. 1):263.

Swanson, K. C., C. J. Richards, and D. L. Harmon. 2002. Influence of abomasal infusion of glucose or partially hydrolyzed starch on pancreatic exocrine secretion in beef steers. J. Anim. Sci. 80:11121116. https://doi.org/10.2527/2002.8041112x.

Timson, D. J. 2019. Fructose 1,6-bisphosphatase: Getting the message across. Biosci. Rep. 39:BSR20190124. https://doi.org/10.1042/ BSR20190124.

Trotta, R. J., L. G. Sitorski, S. Acharya, D. W. Brake, and K. C. Swanson. 2020a. Duodenal infusions of starch with casein or glutamic acid influence pancreatic and small intestinal carbohydrase activities in cattle. J. Nutr. 150:784-791. https://doi.org/10.1093/ jn/nxz319.

Trotta, R. J., M. A. Vasquez-Hidalgo, K. A. Vonnahme, and K. C. Swanson. 2020b. Effects of nutrient restriction during mid- to lategestation on maternal and fetal post-ruminal carbohydrase activities in sheep. J. Anim. Sci. 98:skz393. https://doi.org/10.1093/ jas/skz393.

Turner, R. J., and A. Moran. 1982. Heterogeneity of sodium-dependent D-glucose transport sites along the proximal tubule: Evidence from vesicle studies. Am. J. Physiol. 242:F406-F414. https://doi .org/10.1152/ajprenal.1982.242.4.F406.

Tyler, H., and H. Ramsey. 1993. Effect of fructose induced hypoglycemia on cessation of macromolecular transport in the neonatal calf. J. Dairy Sci. 76:3021-3025. https://doi.org/10.3168/jds.S0022 $-0302(93) 77641-9$

Vandesompele, J., K. De Preter, F. Pattyn, B. Poppe, N. Van Roy, A. De Paepe, and F. Speleman. 2002. Accurate normalization of real-time quantitative RT-PCR data by geometric averaging of multiple internal control genes. Genome Biol. 3:research0034.1.

Walker, D. M. 1959. The development of the digestive system of the young animal III. Carbohydrase enzyme development in the 
young lamb. J. Agric. Sci. 53:374-380. https://doi.org/10.1017/ S0021859600020797.

Walker, J. A., and D. L. Harmon. 1995. Influence of ruminal or abomasal starch hydrolysate infusion on pancreatic exocrine secretion and blood glucose and insulin concentrations in steers. J. Anim. Sci. 73:3766-3774. https://doi.org/10.2527/1995.73123766x.

Wallenfels, K., P. Foldi, H. Niermann, H. Bender, and D. Linder. 1978. The enzymic synthesis, by transglucosylation of a homologous series of glycosidically substituted malto-oligosaccharides, and their use as amylase substrates. Carbohydr. Res. 61:359-368. https:// doi.org/10.1016/S0008-6215(00)84495-X.

\section{ORCIDS}

Alison K. Ward ๑ https://orcid.org/0000-0002-9774-8677

Kendall C. Swanson @ https://orcid.org/0000-0002-5694-4778

\section{APPENDIX}

The following supplemental materials are available online at https://doi.org/10.3168/jds.2020-18145. Supplemental Table S1: Least squares means for the effect of sampling time (before or $2 \mathrm{~h}$ after feeding) on serum glucose and urea-N concentrations; Supplemental Table S2: Least squares means for the effect of day on serum glucose, urea-N, and L-lactate concentrations; Supplemental Table S3: Least squares means for the effect of sampling site on small intestinal mass, protein concentration, mucosal density, and carbohydrase activities; Supplemental Table S4: Least squares means for the effect of sampling site on relative mRNA expression in the small intestine. 